\title{
The Effectiveness of Employee Performance at the Sinjai District Office of Bulupoddo District
}

\author{
Nursyahrul Akil ${ }^{1}$, Haedar Akib², Muh, Nasrullah \\ 1,2,3 Universitas Negeri Makassar \\ Email: akil.syahrulnur@gmail.com
}

\begin{abstract}
Employees are one of the elements of the apparatus that institutionally becomes part of government management to carry out the main tasks and functions in government, development, and community service. This study aims to determine the effectiveness of employee performance at the Bulupoddo District Office in Sinjai Regency. The research method used is descriptive qualitative. Sources of data in this study are primary data sources and secondary data sources. The results of the interviews were obtained from primary data sources referred to as informants, while the main informants, namely the Bulupoddo Sub-District Head while supporting/ordinary informants, namely the staff of the general subdivision and staffing and the people of the Bulupoddo sub-district. The results showed that the effectiveness of employee performance at the Bulupoddo District Office in Sinjai Regency if seen as a whole was effective. This can be seen from the quantity of work, quality of work, knowledge of work, cooperation, determination in work, and initiative.
\end{abstract}

Keywords: Effectiveness: performance: employee

\section{INTRODUCTION}

Regional autonomy or decentralization is considered as one of the reform agendas, where regional governments have the authority to regulate and manage their own regions in accordance with applicable laws and regulations. The implementation of regional autonomy or decentralization opens opportunities or opportunities for a region to be more advanced and developed by utilizing the resources available in its area, a region is directed to accelerate the realization of community welfare by improving services, empowerment, and the role of the community. Regional governments both provincial and district/city have their own regional apparatus to run the wheels of government. One regional apparatus in the district/city is the district.

The subdistrict is one of the regional apparatus that has the authority to take care of matters relating to the fulfillment of services needed by the local community (Dahlan, Hasim, \& Hamdan, 2017; Nasaruddin, 2014). Districts are formed to facilitate the reach of the community in accessing services according to their individual needs so that people no longer have to go to the district/city office (Gani, 2014; Lalaun \& Siahaya, 2016; Lelo, Pandie, \& Tamunu, 2016). The sub-district is the spearhead of the administration of government which is directly confronted by the community. The image of the government bureaucracy as a whole will largely be determined by the performance of the organization. Subdistricts as public service agencies 


\section{6| Jurnal Office: Jurnal Pemikiran Ilmiah dan Pendidikan Administrasi Perkantoran \\ Vol. 6, No. 1, January-June 2020, Page 25-36}

are required to improve and always carry out reforms, as well as anticipating the development of the society that occurs.

In order to improve the image, work, and performance of government agencies towards professionalism and support the creation of good governance, it is necessary to unite the directions and views of all levels of government employees that can be used as guidelines or references in carrying out managerial and operational tasks in all fields of tasks and organizational units in government agencies in an integrated manner (Akib \& Salam, 2016; Isma, Darwis, Saleh, \& Salam, 2017). Improving the administration of government that is oriented towards community service should be emphasized on the district government because the sub-district is the frontline in the implementation of services for the community. Improvements and improvements in the administration of the sub-district government must continue to be made, especially in terms of growing and improving the performance of the subdistrict office apparatus as state servants and public servants who must strive to improve their work capabilities as much as possible, because the implementation of service tasks by the subdistrict government is highly dependent on the performance of its employees, whereas the public can only judge the performance of the sub-district office by the quality of service received.

At present Indonesia is headed for a work-oriented society. To see that work is something noble, does not mean ignoring the people who carry out the work. Likewise in organizations, humans have a very important position. This is because humans become the determinant of whether or not an organization runs towards the achievement of goals which of course depends on the ability of humans to move them. Humans involved in a government organization are called employees.

Effectiveness is a condition that shows how far the plan can be achieved (Kazakovs, Verdina, \& Arhipova, 2015; Raudeliūnienè \& Meidutè-Kavaliauskienè, 2014; Suhariadi, 2013). The more plans that can be achieved, the more effective these activities are so that the word effectiveness can also be interpreted as the level of success that can be achieved from a particular way or business. Performance is the work that can be achieved by a person or group within an organization in order to achieve the objectives (Blaga \& Boer, 2012; Ozkeser, 2019). With the effectiveness, then a description of the performance of an employee's ability can be measured the ability and professionalism of his work when viewed from the concept of the totality of performance effectiveness.

Administratively, government agencies can make performance assessments as a reference or standard in making decisions regarding employee work conditions. Including for promotions at higher career levels, dismissal, and awards or giving employee salaries (Nielsen, Andreasen, \& Alexander, 2005). Therefore, improving the quality of employee work must be done through improving quality and professional performance. Carrying out duties as an employee is working at his or her place of work is not just spending one month while waiting for a salary at the beginning of the month, but employees must pay attention to and prioritize the quality of work (Han, Sun, \& Wang, 2020; Lim, Yu, \& Kim, 2011; Stern \& Becker, 2018).

Improving employee performance must be supported by the encouragement that comes from within employees and encouragement from the environment, to work and apply all the 
potential possessed to carry out basic tasks and functions. Likewise, employees who work in the Bulupoddo Sub-district Office of Sinjai Regency are demanded to be able to provide the best service to the community. The expectation addressed to these employees is to improve quality and professional performance.

\section{METHOD}

This research uses descriptive qualitative research focus to determine the effectiveness of employee performance in the Bulupoddo District Office, Sinjai Regency. The description of the focus in this study is the quantity of work, quality of work, employee knowledge, cooperation, and employee constancy.

There are two sources of data in this study, namely primary data sources: data obtained from interviews (informants) that contain questions relating to the effectiveness of employee performance in the Bulupoddo Sub-district Office, Sinjai District, while the main informant of this study is the Sub-District Head of Bulupoddo, Sub Staff General and Personnel Section, while the usual informants/supporters in this study were two people from Bulupoddo Subdistrict.

Data collection techniques in this study, namely observation, interview, and documentation. The data analysis technique used is data reduction, namely: by recording all information obtained from the results of the interview. The information obtained is then collected and selected information is needed after all the necessary data has been collected an abstraction or summary is made; data presentation, namely: presentation by taking data on the main points but can be guaranteed validity. In presenting data, the information that has been collected is then arranged to make it easier to draw conclusions; draw conclusions, namely: draw problems to enable verification during the study

\section{RESULT AND DISCUSSION}

To find out the effectiveness of employee performance in the Bulupoddo Sub-district Office of Sinjai District, the data processed and presented in this study are data obtained by researchers in the field and adjusted to the grand theory used in this study, namely the theory according to Bernardian and Russell. The results of the analysis of research data conducted at the District Office of Bulupoddo Regency will be described as follows:

\section{Quantity of Work}

Quantity of work is the amount of work done in a specified period. This can be seen from the results of work and the speed at which employees complete their work within a certain time frame. In the context of the performance of sub-district employees, the quantity of work carried out is a reference to whether or not the target is determined by the leadership to the employee or staff in accordance with their duties, also the effective use of time in a job, and the distribution of workloads that is balanced and evenly distributed.

Based on information from the Head of Bulupoddo Subdistrict, Sinjai Regency, it is stated that if it is appropriate or not, God willing, all employees have worked in accordance with their main duties and functions, because they already know what their responsibilities are in working as regulated in existing regulations and also the distribution of workload is evenly distributed to 


\section{8| Jurnal Office: Jurnal Pemikiran Ilmiah dan Pendidikan Administrasi Perkantoran \\ Vol. 6, No. 1, January-June 2020, Page 25-36}

all employees. A similar sentiment was also expressed by the Staff of the Sub Division of General and Personnel of the Sinjai Regency's Bulupoddo District Office who revealed that the employees had worked in accordance with their duties and responsibilities because each employee's duties were clearly arranged so that the employees worked according to their responsibilities, while for workloads, all fields were already burdened with equitable work and so far there have also been no complaints regarding excessive workload. One of the people of Bulupoddo Subdistrict delivered further that if I think yes, it is in accordance with the duties and workload of each because in work employees must already know the boundaries of what is their duty, what their function is as a sub-district employee, and what workload should complete, so that because they already understand what needs to be done and the limits, then in working the employees must adjust to their duties and workload.

Based on the results of the interview the researchers analyzed that, the implementation of the work was in accordance with the duties of each employee and the distribution of workload was evenly distributed to all existing employees. But related to working hours, there were still employees who arrived late even though some other employees were disciplined in terms of attendance.

\section{Quality of Work}

Quality of Work is achieved based on conditions of suitability and readiness that indicate the extent of the quality of an employee in carrying out his duties. The quality of work can be seen through the results of the work done, and what efforts are made to improve the quality of work. Based on the results of interviews found that to measure the quality of employees here, we use indicators of discipline, integrity, and the quality of the work itself. In principle, the work of the employees is quite good. Furthermore, an interview with one of the people of Bulupoddo Sub-district explained that when looking at the overall quality of the employees here, it was already relatively good, I think it was because the employees were accustomed to their work so that they could and the quality was good, but still there had to be an increase in the quality of the district apparatus, especially in terms of providing services to the community.

The results of the interview above, it can be understood that the quality of the work of employees in the Sinja District Bulupoddo District Office is quite good, and service to the community has been carried out to the maximum extent possible. Even though the results of the work quality of employees are already quite good, efforts to improve the quality of work of employees in the Bulukoddo District Office of Sinja Regency still need to be done to achieve more optimal work results and services for the community can be more effective.

To improve the quality of employee work, the efforts made by the Bulupoddo Sub-District Head of Sinjai Regency, namely their efforts by involving employees in training and training to obtain maximum work results so as to increase their knowledge of their work and can be applied here, in addition, to improve the quality of work employees need direct supervision to employees, provide direction, and guidance to employees by holding technical guidance for employees on a regular basis, as well as implementing employee discipline by following morning apples to be more directed to smooth work. While the Staff of the General and Staffing 
Sub Division of the Sinjai District Office of Bulupoddo stated that the efforts made to improve the quality of the work of employees, namely: if the self continues to learn, try to work optimally and obey the rules, while the efforts made by the leadership there is guidance, motivation, training, education and training, morning program to improve employee discipline, and usually there is a staff briefing every time there is a meeting.

Based on the results of the interview above, it can be concluded that the quality of the work results of employees at the Sinjai District Bulupoddo District Office is quite good and efforts to improve the quality of work have also been carried out both from the employees themselves, the sub-district office, and by the government periodically through technical guidance and training, but there are still needs improvements in the implementation of tasks to be more optimal so that the quality of work increases and will automatically increase community satisfaction with the services provided by employees and will further enhance the work ethic of employees in the Sub-District Office of Bulupoddo, Sinjai Regency.

\section{Job of Knowledge}

Knowledge of Employment is the extent to which employees' knowledge of their work and skills, as well as the extent to which employees know the suitability of the work performed with the main duty and Standard Operational Procedure (SOP) that has been determined. Organizational goals will be achieved effectively if employees have knowledge of their work. In the results of the following interview, the researcher will explain the extent to which employees have knowledge of the tasks and functions they handle. In terms of understanding the duties and obligations of employees at work, the Sub-district Head of Bulupoddo, Sinjai District stated that each employee is different, there are those who only understand the extent of their work but do not fully understand, but there are also those who do understand the overall work in the office. In general, all employees already understand the work and responsibilities at work.

Furthermore, the staff of the Sub-Division of General Affairs and Personnel of the Sinjai Regency's Bulupoddo Sub-District Office stated that "if they are in accordance with their respective duties and functions, they already understand what has become their routine duties and obligations in work.

Based on the results of the interview it can be concluded that employees have understood their duties and obligations at work because it has become their daily routine at work. The main duties and functions, as well as the obligations of each employee, have also been set clearly so that the employee more easily understand what is his responsibility at work. If the employee understands the main duties and functions, as well as their obligations, automatically the employee will have reliable knowledge of his work.

\section{Cooperation}

The essence of an organization requires cooperation in order to create a sense of togetherness in the context of achieving common goals that have been set. Organizational goals that have been determined will be achieved effectively if there is a cooperation between members of the organization.

Bulupoddo Sub-District Head of Sinjai Regency stated that until now all employees can still work together in a team even as families, help each other if there is need help and so on, 


\section{0| Jurnal Office: Jurnal Pemikiran Ilmiah dan Pendidikan Administrasi Perkantoran \\ Vol. 6, No. 1, January-June 2020, Page 25-36}

even though sometimes there is a difference in understanding, but it does not last long because as soon as possible resolved as a family, we use one one family team. Furthermore, the staff of the Sub-Division of General Affairs and Personnel of the Sinjai District Bulupoddo District Office also expressed the same thing that in our work we complement each other. This means that we work together to work on existing work and try to help the work of friends who happen to be unable to attend. Because leadership also stressed the importance of cooperation in working.

One community member also stated that sub-district staff could work in teams. This is evidenced by the ability to complete existing work quickly because it is done in collaboration. Furthermore, in terms of employee cooperation, Mr. Baharuddin as a member of the Bulupoddo Subdistrict stated that the cooperation was good because the services provided were good and in terms of service time were classified as fast, if there was no collaboration it would be slow and the management would be difficult.

From the results of the interview, it can be concluded that employee cooperation has been going well and effectively, seen from the cohesiveness of employees in providing fast and optimal service as a form of good cooperation between employees, and helping each other in working.

\section{Persistence at Work}

An employee should have the determination to work wholeheartedly to provide the maximum possible service to the country and society. Persistence in working on this research is an awareness to be trusted in the presence and completion of work as well as possible and on time that must be carried out in order to achieve effective organizational goals. The following researchers describe the results of interviews about the level of attendance of employees at the Sinjai District Office of Bulupoddo District, as stated by the District Head of Bulupoddo Sinjai District that in terms of attendance is quite good. Although sometimes there are still employees who arrive late or are absent, there is a prior notification and an evaluation will be made regarding the attendance of the employee every month.

The opinion above is in line with the staff of the Sub Division of General Affairs and Personnel of the Sinjai District Office of Bulupoddo that most of the attendance of employees have been disciplined. and one of the Bulupoddo Subdistrict community stated that the attendance of employees was quite good even though there were still employees who arrived late.

Then in the next interview with Bulupoddo District community explained that in terms of employee attendance, I think it's good because surely employees already know their working hours and there are employee absences at work, if it is not in accordance with the rules there must be sanctions given including employees who come late. While for the completion and timeliness of employees' work, the Sub-district Head of Bulupoddo Sinjai Regency stated that in general employees have completed their work properly and on time because it has become our program in order to create professional employees, clean and provide optimal service. In work, there are usually two types of work, namely, work that can be done quickly and on time, such as 
a letter of introduction for KTP, KK, SKTM if the requirements are met, then it will be completed in a short act, and there are also jobs that take a long time, such as reports if usually handles things like IPPT (Permit for Land Allotment), Sub-district Musrembang, PNPM (National Community Empowerment Program) activities, and others which are sometimes targeted but the process is not according to the specified time and we are still trying to make improvements in service.

The staff of the Sub Division of General and Personnel of the Sub-District Office of Bulupoddo, Sinjai Regency expressed similar concerns regarding the completion and timeliness of the employee's work stating that it had been done well and completed on time because each employee had understood their main tasks and knowledge and was equipped with knowledge of their work. Furthermore, one of the people of Bulupoddo Subdistrict, Fajar, also said the same thing that in my opinion, they had completed their work as well as possible and on time as when I was taking care of a letter of introduction to make a KTP because all the requirements were complete so the process was fast I just waited a few minutes and the employees worked carefully because several times my file was checked to match the data.

From the results of the interview, it can be concluded that the level of work attendance of employees at the Sinjai Regency Bulupoddo Sub-district Office is good enough, but there are still employees who appear to come outside predetermined or late hours, but in terms of completion and timeliness of work the employee has completed his work as well as possible and on time. This will have an impact on the optimization of services and the effectiveness of employee performance at the Bulupoddo District Office in Sinjai Regency.

\section{Initiative}

The initiative is the ability to do something right without having to be told or ordered. A good employee is an employee who when faced with obstacles or problems, will take the initiative to find the best solution to get out of the problem without waiting for others to ask the problem. In terms of employee initiatives, the Sub-district Head of Bulupoddo Sinjai District stated that sometimes there are jobs that have been completed well by employees with their own awareness without waiting for orders from the leadership and usually there is also work that should require discussion with the leadership but in fact, it has been completed by employees by discussing with fellow employees without asking much from the leadership. In my opinion, it's a good initiative from employees because it proves that they already have the awareness and enthusiasm to work without having to be ordered again.

While the staff of the Sub Division of General and Personnel of the Sub-District Office of the Sinjai District of Bulupoddo stated that if in my Subdivision, usually when there are employees who find obstacles in their work, he immediately asks other employees who might know the solution without having to wait to be asked and what to do. Then the results of an interview with one of the Bulupoddo District community explained that there were still employee initiatives because I saw employees still helping each other in completing tasks and when there were complaints from the community directly addressed without waiting for orders to provide good service to the community.

Based on the results of interviews related to employee initiatives it can be concluded that employees at the Sinjai District Bulupoddo District Office already have initiatives in working in 


\section{$32 \mid$ Jurnal Office: Jurnal Pemikiran Ilmiah dan Pendidikan Administrasi Perkantoran \\ Vol. 6, No. 1, January-June 2020, Page 25-36}

accordance with their duties and responsibilities so that organizational goals can be achieved effectively.

\section{Discussion}

\section{Quantity of Work}

The quantity of work is the amount of work carried out by an employee in a given period. The working quantity of employees at the Sinjai Regency's Bulupoddo Sub-District Office can be seen from the implementation of work that is adjusted to the duties and workload of each employee, as well as based on the use of working hours. The results of the data analysis showed that the implementation of work in the Bulupoddo District Office in Sinjai Regency was in accordance with the main duties and functions of each employee and the distribution of workload was evenly distributed to all existing employees, while related to working hours even though there were still employees who arrived late, but in general, the employees at the Sinjai Regency Bulupoddo Sub-district Office have been working in accordance with working hours.

\section{Quality of Work}

The results of data analysis about the quality of employment of employees at the Sinja District Bulupoddo District Office are quite good, and services to the community have been carried out as optimal as possible, as well as efforts to improve the quality of employee work at the Sinja District Bulupoddo District Office continues to be carried out periodically through technical guidance and training- training to achieve maximum work results and services for the community can be optimized.

\section{Job of Knowledge}

Employee knowledge of work is good. This can be seen from the results of employee analysis which proves that, employees at the Sinjai Regency Bulupoddo District Office already understand their duties and obligations in work, so automatically employees will have reliable knowledge of their routine work..

\section{Cooperation}

The results of data analysis regarding employee cooperation in the Bulupoddo Sub-district Office of Sinjai District showed that employee cooperation has been running well and effectively, seen from the compactness, sense of kinship, and help in working. When there are employees who are unable to attend, then other employees will help carry out the task as long as it does not conflict with applicable rules. From the cooperation that has been running well, making it easier for employees to provide fast and optimal service to the community.

\section{Persistence at Work}

Persistence of employees in working at the Sinjai District Bulupoddo District Office can be seen from the analysis of work attendance, completion of work as well as possible and the 
timeliness of employees who are already quite good even though in terms of attendance there are still employees who arrive late, but evaluation and coaching are continuously held to improve employee discipline that impacts on the optimization of services and effectiveness of employee performance at the Sinjai District Bulupoddo District Office.

\section{Initiative}

Based on the results of the analysis related to employee initiatives it is known that employees at the Sinjai Regency's Bulupoddo Sub-district Office already have initiatives in working in accordance with their duties and responsibilities without having to wait to be instructed again to work, so that with this initiative the completion of employee work will be faster and organizational goals can be achieved effectively.

Based on the research exposure and the results of data analysis, it can be concluded that the performance of the employees at the Bulupoddo District Office in Sinjai Regency has been effective. The effectiveness of employee performance in the sub-district office plays an important role in optimizing the delivery of public services. As state servants and community servants, employees at the Sinjai District Bulupoddo Sub-district Office must make every effort to improve their work abilities, because the implementation of service duties by the sub-district government is highly dependent on the performance of their employees. Whereas the community can only judge the performance of the sub-district office by the quality of the service it receives.

\section{CONCLUSION}

Based on the results of data analysis and discussion that has been described, the conclusions that can be drawn in this study, namely the performance of employees in the Bulupoddo Subdistrict Office of Sinjai District have been effective, seen from the quantity of work assessed from the implementation of work in accordance with the main tasks and functions as well as the distribution of burdens work is evenly distributed to all employees, in general employees are working according to working hours. The quality of work of employees is quite good, service to the community has been carried out as optimal as possible, and efforts to improve the quality of work of employees are still being done regularly. Employee knowledge about work is good is assessed from the employee's understanding of duties and obligations at work. Employee cooperation has been going well and effectively, seen from the compactness, sense of family, and please help in working. Persistence of employees at work is assessed from work attendance, completion of work as well as possible and punctuality of work for employees who are good enough and employees already have the initiative in working.

\section{REFERENCES}

Akib, H., \& Salam, R. (2016). Analisis Kualitas Pelayanan Publik Berbasis Importance 
34| Jurnal Office: Jurnal Pemikiran Ilmiah dan Pendidikan Administrasi Perkantoran Vol. 6, No. 1, January-June 2020, Page 25-36

Performance Analysis (IPA) pada Kecamatan Kota Makassar. Jurnal Ilmiah Scientific Pinisi.

Blaga, P., \& Boer, J. (2012). The Influence of Quality Tools in Human Resources Management. Procedia Economics and Finance, 3, 672-680. https://doi.org/https://doi.org/10.1016/S2212-5671(12)00213-4

Dahlan, D., Hasim, D., \& Hamdan, H. (2017). Pengaruh Manajemen Sumber Daya Manusia dan Budaya Organisasi Terhadap Kualitas Pelayanan Pada Kantor Kecamatan Tamalate Kota Makassar. Jurnal Ad'ministrare: Jurnal Pemikiran Ilmiah Dan Pendidikan Administrasi Perkantoran, 4(2), 69-75.

Gani, F. S. (2014). Respon Masyarakat Terhadap Kinerja Pelayanan Publik Di Kantor Kecamatan Pinogaluman. Jurnal Ad'ministrare: Jurnal Pemikiran Ilmiah Dan Pendidikan Administrasi Perkantoran, 1(1), 62-71.

Han, J., Sun, J.-M., \& Wang, H.-L. (2020). Do high performance work systems generate negative effects? How and when? Human Resource Management Review, 30(2), 100699. https://doi.org/https://doi.org/10.1016/j.hrmr.2019.100699

Isma, E. W., Darwis, M., Saleh, S., \& Salam, R. (2017). Kualitas Pelayanan Administrasi pada Puskesmas Gattareng Kecamatan Gantarang Kabupaten Bulukumba. JURNAL ILMU ADMINISTRASI PERKANTORAN (JIAP), 21-28.

Kazakovs, M., Verdina, A., \& Arhipova, I. (2015). Automation of Human Resources Development Planning. Procedia Computer Science, 77, 234-239. https://doi.org/https://doi.org/10.1016/j.procs.2015.12.379

Lalaun, A., \& Siahaya, A. (2016). Dampak Program Pemberdayaan Terhadap Kesejahteraan Masyarakat Di Kecamatan Yaru Kabupaten Maluku Tenggara Barat. Jurnal Ilmiah Ilmu Administrasi Publik: Jurnal Pemikiran Dan Penelitian Administrasi Publik, 5(2), 73-78.

Lelo, L., Pandie, D., \& Tamunu, L. (2016). Implementasi Kebijakan Pembangunan Kelembagaan Pemerintah Kecamatan Sebagai Perangkat Daerah (Studi Di Kota Kupang Dan Kabupaten Sikka). Jurnal Ilmiah Ilmu Administrasi Publik: Jurnal Pemikiran Dan Penelitian Administrasi Publik, 6(1), 1-10.

Lim, C.-W., Yu, J.-H., \& Kim, C.-D. (2011). The development of work performance analysis system. Automation in Construction, 20(1), 28-36. https://doi.org/https://doi.org/10.1016/j.autcon.2010.07.007

Nasaruddin, H. (2014). Kualitas Pelayanan Kesehatan Di Pusat Kesehatan Masyarakat Kecamatan Pattallassang Kabupaten Gowa. Jurnal Ad'ministrare, 1(1), 28-38.

Nielsen, J., Andreasen, A., \& Alexander, A. (2005). Promotion of work ability at company level: Intention and performance, dreams and realities. International Congress Series, 1280, 386-391. https://doi.org/https://doi.org/10.1016/j.ics.2005.02.093 
Ozkeser, B. (2019). Impact of training on employee motivation in human resources management. Procedia Computer Science, 158, 802-810. https://doi.org/https://doi.org/10.1016/j.procs.2019.09.117

Raudeliūnienè, J., \& Meidutè-Kavaliauskienè, I. (2014). Analysis of Factors Motivating Human Resources in Public Sector. Procedia - Social and Behavioral Sciences, 110, 719-726. https://doi.org/https://doi.org/10.1016/j.sbspro.2013.12.916

Stern, H., \& Becker, T. (2018). Influence of work design elements on work performance and work perception - an experimental investigation. Procedia CIRP, 72, 1233-1238. https://doi.org/https://doi.org/10.1016/j.procir.2018.03.077

Suhariadi, F. (2013). Manajemen Sumber Daya Manusia: Dalam Pendekatan Teoritis-Praktis. Surabaya: Airlangga University Press. 
36| Jurnal Office: Jurnal Pemikiran Ilmiah dan Pendidikan Administrasi Perkantoran Vol. 6, No. 1, January-June 2020, Page 25-36 